\title{
Influence at the Founding: The Federalist Papers' Effect on the Ratification of the Constitution in the State of New York
}

\author{
Derek Schutz
}

\begin{abstract}
While the drafting of the American Constitution in the summer of 1787 is recognized as a contentious period, the ratification of the proposed Constitution in each of the states held its own challenges. The Federalist Papers are widely seen as providing the case for the confidentially crafted Constitution, particularly in the state of New York. Yet the extent to which they played a role in convincing citizens and delegates at the time remains unclear. This essay seeks to understand the role that these 85 Federalist Papers played in the Ratification debate in the state of New York.
\end{abstract}

The Constitution of the United States of America is today cherished as one of the most important political documents of the modern age. The Federalist Papers, a series of essays written in defense of the Constitution, are seen as playing an important role in the debate occurring in the 1788 ratification of the Constitution. Yet the purpose of the series of essays was to argue for the ratification of the Constitution in the State of New York. The question of whether they were successful in this respect is still up for debate. Despite their unparalleled breadth and clarity, the Federalist Papers likely did not positively affect the ratification process in the state of New York or elsewhere. Several facts lead one to this conclusion. First, the Federalist Papers were not widely published in the colonies. Second, even after the publishing of the Papers, two-thirds of New York delegates came out in opposition to the Constitution. Finally, the length of time it took the New York convention to come to a decision shows that few were swayed by the arguments put forth in the Federalist Papers and the arguments given by its authors at the Convention. Before this can be shown a recounting of the events leading up to the New York convention is necessary.

The roots of the pursuit of a new constitution in the United States stretch as far back as the American Revolution. It was upon the filing of the Declaration of Independence that thirteen republics would embark on a journey towards collective statehood. The Declaration of Independence of 1776 and the subsequent Articles of Confederation would define the loose confederation of states following the War. At this point, the former colonies-turnedstates would have seen themselves as distinct political units, not as a single country. ${ }^{1}$ This was reflected in the Articles of Confederation which gave very little power to the congress that 'governed' the confederation; indeed, the Congress was not even able to tax the citizens of the states to pay back the debt the confederation had incurred during the war. ${ }^{2}$ These and other frustrations led to the creation of a Constitutional Convention in 1787 to which each state was to send delegates. Out of this Convention would result a document which would be hotly debated.

\footnotetext{
${ }^{1}$ Edward Wood, Empire of Liberty: a history of the early republic, 1789-1815, (Oxford: Oxford University Press, 2009), 7.

${ }^{2}$ Ibid., 15.
} 
The debate following the Convention began when two delegates representing New York at the convention, John Lansing Jr. and Robert Yates, left the Constitutional Convention on principle. They strongly disagreed with the notion of a strong centralized government. Their absence left the New York delegation without any authority since each delegation needed a minimum of two delegates present to vote. ${ }^{1}$ The only remaining New York delegate was Alexander Hamilton, a former aide-de-camp to General George Washington and representative in New York State's legislature. Violating the Convention's oath of silence, Lansing and Yates reported to New York's governor, George Clinton, on the direction of the proceedings towards a strong central government. ${ }^{2}$ Clinton soon came out in opposition to the Constitution, prompting Hamilton to write an anonymous letter in the July 21, 1787 issue of the New York Daily Advertiser. In it he denounced Clinton's early opposition. ${ }^{3}$ Clinton, writing under the pseudonym Cato, responded in late September of the same year with what would be a series of essays opposed to the new Constitution. ${ }^{4}$

Two camps formed coming out of the Convention, the Federalists and the Anti-Federalists. The Federalists, whose name evokes a federation of states, supported the new Constitution favoring a centralization of power under one government. The Anti-Federalists opposed the Constitution, favoring more powerful states and a greater focus on individual rights. ${ }^{5}$ Federalist and Anti-Federalist writers soon filled the press with reasoned and defamatory essays. And so began the war of words in the presses that would lead up to the publication of the first Federalist Paper in the New York Independent Journal on October 27, $1787{ }^{6}$

The Federalist Papers were written in the aftermath of the Constitutional Convention in Philadelphia under the pseudonym 'Publius.' Two of the authors behind the pseudonym, Alexander Hamilton and James Madison, were delegates at the convention for New York State and Virginia respectively. Madison, after a term in the Virginia State Legislature, crafted the Virginia Plan during the Constitutional Convention whereby the concept of a congress based on representation by population was suggested. In fact, both Madison and Hamilton were part of the five-man committee that drafted the Constitution. ${ }^{7}$ John Jay, author of only five of the Papers, held positions in the Continental Congress ranging from Diplomat to Secretary of Foreign Affairs, but was not involved in the Constitutional Convention. ${ }^{8}$

While it is disputed who authored which essay, it is generally agreed that Hamilton penned fifty-one papers, James Madison twenty-nine and John Jay five, totaling eighty-five. ${ }^{9}$ The papers were published over a seven month period throughout the fall and winter of 1787

\footnotetext{
${ }^{1}$ Ron Chernow, Alexander Hamilton, (New York: The Penguin Press, 2004), 235-236.

${ }^{2}$ Ibid., 235-236.

${ }^{3}$ Bruce Chadwick, Triumvirate: The Story of the Unlikely Alliance that Saved the Constitution and United the Nation, (Naperville: Sourcebooks Inc, 2009), 201.

${ }^{4}$ Chernow, Alexander Hamilton, 245.

${ }^{5}$ Carol Berkin, A Brilliant Solution: Inventing the American Constitution, (New York: Harcourt Inc, 2002), 175.

${ }^{6}$ Elaine F. Crane, "Publius in the Provinces: Where was "The Federalist" Reprinted outside New York City?" The William and Mary Quarterly Third Series, Vol. 21, No. 4 (Oct 1964): 589, Accessed November 22, 2010, http://www.jstor.org/stable/1923310.

${ }^{7}$ Chernow, Alexander Hamilton, 239.

${ }^{8}$ Berkin, A Brilliant Solution..., 62.

${ }^{9}$ Chernow, Alexander Hamilton, 248.
} 
and into the spring of $1788 .^{1}$ The Papers were then collected in two bound volumes distributed to delegates from State Conventions and sold across the nation starting in late March of $1788 .^{2}$

The new Constitution had to be ratified by independently elected State conventions which were strategically staggered to build momentum leading up to the Virginia and New York conventions. ${ }^{3}$ Delaware, Pennsylvania, and New Jersey ratified the Constitution as early as December, 1787 and Connecticut, Georgia and Massachusetts had ratified by February, 1788. ${ }^{4}$ New York State did not select delegates for the convention till April, 1788. Here, Federalist delegates were elected to only a third of the seats at the convention and then only from districts in and around New York City. ${ }^{5}$

The New York convention did not meet until June 14, 1788 in Poughkeepsie, New York. ${ }^{6}$ The Federalists were headed by Alexander Hamilton, Robert Livingston, the first Chancellor of New York State, and John Jay. ${ }^{7}$ The Anti-Federalists were headed by Governor Clinton and Melancton Smith, likely author of the popular Anti-Federalist 'Federal Farmer' articles. ${ }^{8}$ At the outset, Hamilton slipped in a provision requiring the Convention to debate the Constitution line by line, something he and his colleague John Jay were well prepared for, having spent months writing the Federalist Papers. ${ }^{9}$ The Convention lasted well into July even after the ninth state, New Hampshire, had ratified. This ensured the formation of a new Union. In fact, New York was the last major state to ratify, holding off even after Virginia. ${ }^{10}$ Debate lasted until July 26, 1788, when, with the support of Melancton Smith, the Constitution was passed by a slim margin of thirty to twenty-seven. ${ }^{11}$ Not only had the New York Convention started late, but efforts to avoid conditional approval of the Constitution had added nearly two weeks of debate. ${ }^{12}$ Throughout and leading up to New York's convention, however, it can be shown that the Federalist Papers did not significantly affect the ultimate ratification of the Constitution.

The first indicator of the Papers' failure to influence was their inaccessibility outside of New York City. This is due both to a lack of publication in newspapers outside the city and to a lack of demand for the collection of the Federalist papers in book format. The Federalist Papers were published by four of New York City's seven newspapers. ${ }^{13}$ However, only sixteen of the eighty-nine newspapers and three magazines published in the states between

${ }^{1}$ Ibid.

${ }^{2}$ Crane, "Publius in the Provinces...", 590.

${ }^{3}$ Chernow, Alexander Hamilton, 261-262.

${ }^{4}$ Ibid., 261.

${ }^{5}$ Berkin, A Brilliant Solution..., 189.

${ }^{6}$ Chernow, Alexander Hamilton, 263.

${ }^{7}$ Robin Brooks, "Alexander Hamilton, Melancton Smith, and the Ratification of the Constitution in New York" The William and Mary Quarterly Third Series, Vol. 24, No. 3 (July 1967): 346, Accessed November 22, 2010, http://www.jstor.org/stable/1920872.

${ }^{8}$ Chadwick, Triumvirate..., 147.

${ }^{9}$ Ibid.

${ }^{10}$ Berkin, A Brilliant Solution..., 187.

${ }^{11}$ Brooks, "Alexander Hamilton, Melancton Smith...", 355-356.

${ }^{12}$ Ibid, 351-355.

${ }^{13}$ Crane, "Publius in the Provinces...", 590.

Constellations

Volume 2, No. 2 (Winter 2011) 
late October 1787 and late July 1788 reprinted any of the Federalist Papers. ${ }^{1}$ Only twelve newspapers in states other than New York published any of the Papers. Furthermore, these newspapers were published only in the states of Massachusetts, Virginia, Pennsylvania, and Rhode Island and none of these printed anything close to the full eighty-five Papers. Even the newspapers carrying reprints neglected to feature the majority of the Papers. In fact, "only twenty-four of the Papers were printed in newspapers outside New York City." It is clear that the Papers were not widely viewed in states other than New York. Even in rural New York State the Papers were not widely published.

In New York State, the Albany Gazette featured twelve Papers and the Hudson Weekly Gazette featured eleven Papers. The Northern Centinel in Lansingburgh and Federal Herald in Albany together published eleven and the Country Journal in Poughkeepsie, the location of New York's convention, featured seven. ${ }^{3}$ Considering that the whole of the Federalist numbered eighty-five papers, this certainly did not amount to a complete publication. While New York City newspapers circulated throughout the state, Elaine F. Crane concludes that based, "Publius did not reach an audience of any significant size in 1787-8." Furthermore, Carol Berkin notes that the essays supporting the Federalist cause, like the Federalist Papers, were published in newspapers which were predominately urban. ${ }^{5}$ This lack of availability alone greatly decreases the Papers' possible influence on the citizenry leading up to the election of delegates to the New York convention.

The Federalist Papers were also collected and published in two volumes, the first appearing on March 22 and the second on May 28, 1788. The two volumes, however, were vastly outsold by pamphlets containing Anti-Federalist essays from the Federal Farmer. ${ }^{6}$ It was not until 1799 that the Federalists completely sold its first run, suggesting a lack of demand. ${ }^{7}$ Five-hundred copies were sent free of charge to delegates in a variety of states. Of these, a large number were sent to Poughkeepsie, the site of the New York convention, for "gratuitous distribution." "Y Yet these likely failed to reach many non-Federalists since the Poughkeepsie volumes were distributed to Federalists at one of their meetings. ${ }^{9}$ Pauline Maier notes "the Federalist was probably no more effective among the people of rural New York than Mercy Warren's Columbian Patriot," also a pamphlet meeting with scanty distribution. $^{10}$

The Papers' narrow circulation may have been the reason behind the crushing defeat of Federalists in the ratification convention election in upstate New York. In fact, the Federalists failed to win any delegates outside of New York and the neighboring Kings,

${ }^{1}$ Ibid.

${ }^{2}$ Ibid.

${ }^{3}$ Ibid.

${ }^{4}$ Ibid., 591.

${ }^{5}$ Berkin, A Brilliant Solution..., 174.

${ }^{6}$ Linda G. De Pauw, The Eleventh Pillar: New York State and the Federal Constitution, (Ithaca: Cornell University Press, 1966), 112.

${ }^{7}$ Chadwick, Triumvirate..., 85.

${ }^{8}$ De Pauw, The Eleventh Pillar..., 112.

${ }^{9}$ Pauline Maier, Ratification: the People Debate the Constitution, 1787-1788, (New York: Simon and Schuster, 2010), 336

${ }^{10} \mathrm{Ibid}$.

Constellations

Volume 2, No. 2 (Winter 2011) 
Richmond, and Westchester counties. ${ }^{1}$ The loss was so bad that at the beginning of the New York Convention Anti-Federalist delegates numbered forty-six while the Federalist delegates numbered only nineteen. ${ }^{2}$ Of the delegates, Melancton Smith was the only Anti-Federalist who actually resided in New York City. ${ }^{3}$ This overall lack of Federalist representation, particularly outside of New York City, goes to show how little effect the Federalist Papers had on the population in rural New York State.

This begs the question: were any Anti-Federalists exposed to the Federalist's arguments actually swayed by Publius? This seems unlikely for several reasons. First, the Federalist papers, as demonstrated by the most popular of its numbers, Federalist 10, are deep discussions of philosophical ideas like the nature of man and social contract theory. Federalist 10, written by Madison, is a refutation of Montesquieu's principle that democracies must necessarily be small, and bases its argument on the assumption that "the latent causes of faction are thus sown in the nature of man." Federalist 10 is an amalgam of the philosophies of David Hume, Adam Smith and other writers of the Scottish Enlightenment. ${ }^{5}$ Federalist 10, according to Robert Dahl, is "a more compactly logical, almost mathematical piece of theory than anything ever written by an American." "This complexity, combined with other factors, likely limited the Papers' accessibility for many readers.

The length of the collected Federalist Papers was another factor contributing to the Papers' inaccessibility. The Papers' length likely proved to be an obstacle for many potential readers in New York State. Maier notes that the collected Papers numbered over six-hundred pages. ${ }^{7}$ Considering that voting for delegates to the New York convention began on April 29, 1788 only one of the two volumes of the collected Papers would have been available and only a month earlier on March 22, $1788 .^{8}$ Problems with distribution aside, this short availability of the Papers before the vote would make the Papers particularly inaccessible to many urban and rural readers. Many of the voting public would not have the time to digest such a treatise in just over a month. Linda Grant De Pauw notes that "the Federalist actually had little value as propaganda." Compared to writings by Anti-Federalist pamphlets that could be easily printed and circulated, the collected Papers amounted to an unwieldy tome. ${ }^{10}$

Moreover, many commentators found Publius's arguments at best unconvincing and, worse, confounding. Monsieur Otto, a French diplomat of the time, is widely quoted as saying that the essays "were of no value whatever to well informed people, and [...] too learned and too

\footnotetext{
${ }^{1}$ Berkin, A Brilliant Solution..., 189.

2 Brooks, "Alexander Hamilton, Melancton Smith...," 346.

${ }^{3}$ Ibid, 357.

${ }^{4}$ James Madison, "Federalist Number 10, 1787," In Reading the American Past: Selected Historical Documents Volume I: To 1877, $4^{\text {th }}$ edition, edited by Michael P. Johnson, 154-159, (Boston: Bedford/St. Martin's, 2009), 156; Chernow, Alexander Hamilton, 254.

${ }^{5}$ Robert A. Rutland, James Madison: The Founding Father, (Columbia: University of Missouri Press, 1987), 30 .

${ }^{6}$ Ibid., 31.

${ }^{7}$ Maier, Ratification, 84 .

${ }^{8}$ Ibid, 340.

${ }^{9}$ De Pauw, The Eleventh Pillar..., 114.

${ }^{10}$ Ibid.
} 
long for the ignorant." ${ }^{\prime 1}$ De Witt Clinton, in his "Countrymen" essays, wrote in 1788 that

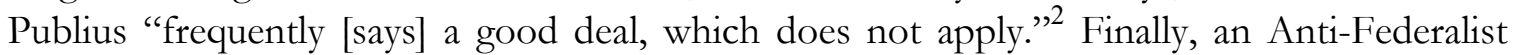
commentator noted that The Federalist "was not well calculated for the common people.",

De Pauw adds that the Papers may even have addressed the wrong issues. She notes that while Publius tries to convince his readers of the need for a strong centralized government, what was really needed were assurances that such a government "would not endanger personal liberty." 4 The Papers' inefficacy could have been due to a number of reasons: a lack of understanding, a lack of time, or a lack of any convincing arguments. What is certain though is the Federalist Papers failed to persuade voters in upstate New York to favor the Federalist position. One could argue that, despite the convention's eventual ratification of the Constitution, the Federalist Papers were also ineffective in persuading the Anti-Federalist delegates at the convention in Poughkeepsie.

The length of the convention and the ultimate reason for the Constitution's ratification reveal the ineffectiveness of Federalist arguments on the predominately Anti-Federalist delegates. The New York convention began on June 14, 1788 but was unable to come to a decision on the matter of the Constitution until the July 26, 1788. While Hamilton calculated that the ratification of the Constitution in the states of New Hampshire and Virginia would have a positive effect on the proceedings in New York, this turned out not to be the case. ${ }^{5}$ Virginia ratified the Constitution on June 25, 1788, and New York was told of the ratification on July 2 , nearly a month before New York itself would vote. ${ }^{6}$ The prospect of being the only major state outside the union was not enough to convince New York to ratify, and delegates debated for nearly a month further. Only in the face of the possibility of the cessation of New York City and potential civil war did several Anti-Federalist delegates vote with the Federalists in favor. ${ }^{7}$ De Pauw notes that recognition of the threat of cessation first came from a Philadelphia essayist on May 16, $1788 .^{8}$ This sentiment was echoed by Hamilton in a speech at the New York convention on July 11, $1788 .^{9}$ Even this ratification came with the condition that the states would consider amendments and a slim margin of victory of thirty to twenty-seven. ${ }^{10}$

Further admissions by several important players in the New York convention revealed the extent of the Federalist arguments' futility. Melancton Smith, the most important AntiFederalist who voted for the Constitution, was one of these players. ${ }^{11}$ During the convention he remarked that Hamilton "has like Publius much to say not very applicable to the subject." 12 So, not only did one Anti-Federalist connect Hamilton's arguments in the

\footnotetext{
${ }^{1}$ Ibid., 115.

${ }^{2}$ Ibid., 116.

${ }^{3}$ Chadwick, Triumvirate..., 84.

${ }^{4}$ De Pauw, The Eleventh Pillar..., 116.

${ }^{5}$ Chernow, Alexander Hamilton, 262.

${ }^{6}$ Chernow, Alexander Hamilton, 267; Carol Berkin, A Brilliant Solution: Inventing the American

Constitution, (New York: Harcourt Inc, 2002), 187.

${ }^{7}$ Chernow, Alexander Hamilton, 268.

${ }^{8}$ De Pauw, The Eleventh Pillar..., 232-233.

${ }^{9}$ Brooks, “Alexander Hamilton, Melancton Smith...," 350.

${ }^{10}$ Chernow, Alexander Hamilton, 268.

${ }^{11}$ Brooks, "Alexander Hamilton, Melancton Smith...," 357.

${ }^{12}$ Ibid., 349.
}

Constellations

Volume 2, No. 2 (Winter 2011) 
convention with those in the Federalist, but dismisses both out of hand. Smith recognized Hamilton's arguments were similar to those found in the Federalist Papers, but that neither are convincing. If the most important Anti-Federalist who did vote for the Constitution was unconvinced by the Papers then those Anti-Federalists who did not vote for the Constitution certainly were no more convinced.

Even Hamilton confided to Madison in a note during the convention that "our arguments confound, but do not convince." Here, Hamilton, the main author of the Federalist Papers, admitted the arguments he and his coauthor Madison used in writing the Federalist Papers, the same arguments Hamilton presented at the New York convention, failed to convince the delegates.

The Federalist Papers, therefore, had little influence on the ratification of the Constitution of the United States in New York State. This was evident in the Papers' lack of effect on voters leading up to the election of delegates and on the delegates themselves during the convention. This first problem was likely caused by the relative lack of a wide distribution and the length and complicated nature of the Papers. The cause of the second problem seems to be much deeper: Publius's arguments, echoed by Hamilton at the convention, failed to convince the Anti-Federalist delegates. While today revered as the philosophical basis for the United States Constitution, the Federalist Papers had little effect on the ratification process in the state of New York. With this in mind, the Federalist Papers occupied a somewhat different place in the ratification process. While the arguments within the Papers are no less potent and applicable, their historical significance during this period is considerably diminished.

${ }^{1}$ Ibid., 339.

Constellations

Volume 2, No. 2 (Winter 2011) 


\section{Bibliography}

Berkin, Carol. A Brilliant Solution: Inventing the American Constitution. New York: Harcourt Inc. 2002.

Brooks, Robin. "Alexander Hamilton, Melancton Smith, and the Ratification of the Constitution in New York." The William and Mary Quarterly Third Series 24, 3. 1967. 339-358. Accessed November 22, 2010.

Chadwick, Bruce. Triumvirate: The Story of the Unlikely Alliance that Saved the Constitution and United the Nation. Naperville: Sourcebooks Inc. 2009.

Chernow, Ron. Alexander Hamilton. New York: The Penguin Press. 2004.

Crane, Elaine F. "Publius in the Provinces: Where was "The Federalist" Reprinted outside New York City?" The William and Mary Quarterly Third Series 21, 4. 1964. 589-592. Accessed November 22, 2010.

De Pauw, Linda G. The Eleventh Pillar: New York State and the Federal Constitution. Ithaca: Cornell University Press. 1966.

Furtwangler, Albert. The Authority of Publius: a Reading of the Federalist Papers. Ithaca: Cornell University Press. 1984.

Madison, James. "Federalist Number 10, 1787." In Reading the American Past: Selected Historical Documents Volume I: To 1877, 4th edition, edited by Michael P. Johnson. Boston: Bedford/St. Martin's. 2009. 154-159.

Maier, Pauline. Ratification: the People Debate the Constitution, 1787-1788. New York: Simon and Schuster. 2010.

Rutland, Robert A. James Madison: The Founding Father. Columbia: University of Missouri Press. 1987.

Wood, Edward. Empire of Liberty: a bistory of the early republic, 1789-1815. Oxford: Oxford University Press. 2009. 